\title{
3 \\ FACING NEW REALITIES: FROM HOLSWORTHY TO NUI DAT
}

Stan Maizey

\section{Editors' introduction}

Stan Maizey was second in command of 5th Battalion, the Royal Australian Regiment (5 RAR), from January 1966 until December 1966, when he was posted as the senior operations staff officer at Headquarters, 1st Australian Task Force (HQ 1 ATF). He spent 16 months in Vietnam, eight months each with 5 RAR and HQ 1 ATF. Stan, sadly, died on 18 June 2018, while this book was still being written. Fortunately, several years ago, he had written an article about his experiences with 5 RAR and he agreed that this could be published in Vietnam Vanguard.

This chapter is about 5 RAR's preparations for its first tour of duty in Vietnam, and the inherent logistic difficulties encountered. Getting ready for a lengthy period of war service is a complex process, especially in terms of assembling the necessary equipment. As second in command of the battalion, it was principally Stan's responsibility to see that we went to war with all our necessary equipment. If we could not get all that we needed in Australia, he then had to negotiate with the Americans to make up for the deficiencies in equipment and other essential supplies. Bearing in mind that Australia had not sent a multi-battalion-sized force abroad on operations since the Korean War of the early 1950s, there was much to be 
done in terms of equipping and supplying 5 RAR and 6 RAR before they went to Vietnam in April 1966. Here is Stan's account of how he met the challenges confronting him in 5 RAR's initial year of service in Vietnam.

\section{Stan Maizey}

I was posted as second in command (2IC) of 5 RAR in December 1965, arriving at Gallipoli Barracks, Holsworthy, in early January 1966. The commanding officer (CO), Lieutenant Colonel John Warr, was visiting 1 RAR at Bien Hoa, South Vietnam, but had left instructions for the training he required until his return.

At this stage, the battalion was a nucleus of regular army officers, noncommissioned officers and men. Reinforcements started to arrive from September 1965 and included many national servicemen (NS) from the Officer Training Unit, Scheyville (near Windsor, NSW), and from the various NS recruit training battalions.

While no official announcement had been made, it was understood that 5 RAR would replace 1 RAR in Vietnam in April/May 1966. Correspondence between counterparts of the battalions was taking place and the logistic information included: bring as much timber/flooring as possible; scale holdings of consumable items for at least six months, not three months as shown in the various equipment tables; get a fisheye lens for the movie projector; be aware of the various US codes and code words (such as Dustoff, for casualty evacuation), and requisition procedures; and get used to US rations.

The battalion's training concentrated on shooting, platoon drills, company movement, helicopter familiarisation and getting to know one another. During February and early March 1966, each company was phased through a company training exercise in the Gospers Training Area, near Rylstone, NSW, and evaluation at the Jungle Training Centre, Canungra, Qld. Finally, in March a battalion exercise under the direction of the CO took place in the Gospers Training Area to be followed immediately by an assessed exercise under the direction of HQ 1st Task Force at Holsworthy.

During this training, the quartermaster's $(\mathrm{QM})$ staff were extremely busy ensuring that the battalion was properly equipped. Unfortunately, the army's supply depots refused to accept our requisitions as we submitted 
them in a multi-listed format, and not by single items (that is, one item to one page). Achieving this level of detail required all the battalion's clerks to be seconded to the QM for about 10 days to rewrite the paperwork. Then, because no formal announcement had been made regarding 5 RAR replacing 1 RAR in Vietnam, our requisitions for any items in the infantry battalion equipment tables - which were designated as restricted warlike stores - were endorsed 'Not Approved' and returned to us. Lastly, when we tried to follow 1 RAR's advice to scale our holdings for six months (instead of the customary three months), the staff officers at HQ Eastern Command either refused to approve an extra holding or replied, 'the items are to be taken over from 1 RAR in situ'. It was not until late February or early March 1966, after the announcement that the Australian commitment was to be significantly increased to a two-battalion task force with supporting arms and a logistic support group named 1st Australian Logistic Support Group (1 ALSG), that our demands were reluctantly processed. However, with the introduction of national service in June 1965, many items of clothing and equipment were in short supply and the army's procurement system proved sadly inadequate. For example, some soldiers had only one set of jungle green uniforms (other than protective dress, which was usually an outdated but recycled khaki summer uniform). Most soldiers had only one pair of calflength general purpose (GP) boots with protective stainless-steel inserts in the soles, so each soldier was issued with a pair of 1944-era tropical studded ankle boots and a pair of canvas gaiters (leggings). All soldiers had their full entitlement of personal load-carrying equipment and there was little or no reserve in the battalion QM Store.

The final training exercise saw the battalion using a range of equipment recently received and still in protective packaging. The exercise was held in foul weather so, with the connivance of the regimental medical officer (RMO), we managed to get a rum issue for all ranks through the supply system.

During the preparatory phase, and on advice from 1 RAR, we tried to shed our anti-tank (ATk) weapons: an $84 \mathrm{~mm}$ rocket launcher (Carl Gustav) held by each of the rifle companies; and six $106 \mathrm{~mm}$ recoilless rifles (RCLs) held by the Anti-Tank Platoon. Sadly we were unsuccessful in this endeavour. The RCLs were mounted on modified Land Rovers and, after discussion within the battalion, our armourer, Sergeant Mick Henrys, suggested that we mount a machine gun on each vehicle, primarily for convoy protection. These six vehicles became known as 'Sports Cars' and 
were invaluable in their adapted, albeit technically illegal, role. We were required to take the anti-tank equipment to war where it languished in the QM Store, except for two $106 \mathrm{~mm}$ RCLs, which were located on either side of the flag pole 'guarding' Battalion Headquarters in the base area. At the same time, and with a submission by 1 RAR to support our request, we tried to amend the equipment table to obtain more M60 general purpose machine guns (M60 GPMG), radios and telephones for base area defences, but this was refused with the comment 'not until the CO has personally established the need'. How we overcame these deficiencies is told later in this chapter.

During the build-up of men and materials, as bad as the ordnance stores supply system was, the engineer and medical systems were magnificent. The engineer system provided us with a good supply of timber and the School of Military Engineering at Casula provided instructors for training in the use of mines and booby traps, barbed wire fencing and sandbagging. The medical system, particularly 2 Camp Hospital at Ingleburn, provided instructors for first aid, health and hygiene training, and vital associated stores. They also gave high priority to members of the battalion with respect to inoculations.

In April 1966, the battalion Advance Party flew out, to be initially fostered by 1 RAR at Bien Hoa, then to proceed to the sand dunes at Vung Tau to establish a camp for the battalion prior to the occupation of the 1 ATF base at Nui Dat. C Company and all the battalion's stores, equipment and vehicles departed in mid-April 1966 on HMAS Sydney, while the remainder of the battalion flew out from Richmond Royal Australian Air Force (RAAF) base in Boeing 707s over a period of three weeks. In mid-May 1966 the last element of the battalion, including myself, departed for South Vietnam. On arrival at Saigon's Tan Son Nhut airport, we disembarked and collected our weapons and equipment. We then embarked on a US C123 Provider transport aircraft for the flight to Vung Tau. We waited nearly two hours inside the aircraft, in atrocious heat and humidity, before take-off.

On arrival in Vietnam, it was immediately obvious that some of the stores and equipment we were required to take over from 1 RAR were unserviceable from 12 months of hard use, especially tentage and M16 rifles. The rifles arrived without cleaning accessories and our armourers were required to fashion cleaning rods from heavy gauge fencing wire. 
Life at Vung Tau was hectic as we acclimatised, and got to know our supporting troops and their jargon, and conducted aerial reconnaissance of Phuoc Tuy Province (some of these flights were decidedly hair-raising). The US Army's 68 Assault Helicopter Company, based at Vung Tau air base, deserves special mention because this unit provided wonderful support whenever required. Prior to leaving Vung Tau, we had an officers' dining-in night at the Pacific Hotel (a big French colonial hotel taken over by the US troops as officers' quarters) where the aviators were present. The battalion provided the cooks and stewards and the Battalion Band played a tremendous rendition of 'Those Magnificent Men in their Flying Machines', which brought the house down.

Operation Hardihood, the clearing and then occupation of the Task Force's operational base at Nui Dat, began in mid-May 1966, initially conducted by the US 173 Airborne Brigade with, in late May 1966, 5 RAR placed under its command for the final phase of the operation. The battalion was assisted by a company of 1 RAR. During the operation, the battalion was very active to the north of Nui Dat and had many contacts, mostly with groups of three to five Viet Cong (VC).

In early June 1966, our contacts with the enemy diminished, and it was decided to commence occupation of the Task Force base at Nui Dat. Prior to the administrative echelons of the battalion and the Task Force moving into the area, we were warned of a likely assault by 274 Viet Cong Regiment. The $\mathrm{CO}$ called for an urgent resupply of ammunition, particularly belted ammunition for the M60 machine guns, Claymore mines and mortar rounds. While the ammunition was being gathered, I asked for helicopter support, from the US Army's 68 Assault Helicopter Company to lift the heavy loads forward. Our QM Platoon had removed most of the packaging to reduce weight and bulk, but there was still considerably more to move. When the helicopters arrived, I asked a pilot how much weight could be carried by each aircraft. With typical US nonchalance, the pilot replied, 'Fill it [the aircraft] up'. When we could put no more aboard, he gave the thumbs up, lifted off about one metre, bounced the aircraft to about three metres then moved forward, settled, bounced again and was finally airborne. 
Life at Nui Dat was a constant struggle - against the elements (the wet monsoon season had started), the stores and equipment shortages, the discomforts of 'home', the inability to defend the base adequately when the battalion was out on an operation - all endured while developing the base's defence works.

Many problems complicated our efforts. With the wet season, each time a weapon pit was dug and before any overhead cover/protection could be found, the pit filled with water. Thank goodness the weather was not cold. Trying to fill sandbags with wet clay, the predominantly available filling material at Nui Dat, was extraordinarily difficult so, whenever possible, I would send a convoy of Land Rovers and trailers to Vung Tau to fill sand bags with sand. Whenever the battalion was on operations there were only three radios (mine and those of the officer commanding (OC) Administration Company and the QM) left in the battalion's base area. Our field telephones were required on operations, therefore we literally used message sticks for communications between company positions at Nui Dat until the 'Scrounging Platoon' (formed in country for obvious reasons and consisting of company 2ICs, company quartermaster sergeants and most of Administration Company) found, by the side of the road, an unattended switchboard, some telephones and radios. The other, and most worrying, deficiency was a lack of machine guns for the defence of the base. Administration Company had a handful of heavy-barrelled rifles, capable of magazine-fed automatic fire, but nothing more by way of defensive weapons. Again, the Scrounging Platoon, by exchanging a couple of slouch hats and some butter with our allies, gained several .30 and .50 calibre machine guns. The former were immediately mounted onto the Sports Cars and the latter were positioned in bunkers in the company areas. Further defence and other base stores were obtained when the Scrounging Platoon under my command, and using our Land Rovers and trailers, visited the US Supply Depot at Vung Tau. We left the Depot with all trailers full of borrowed stores, a stores truck and a water truck. After we spent most of the day at the 'supermarket', the new guard on duty demanded written authorisation, which of course we did not have. As it was getting very late and because the road to Nui Dat was classified black (unsafe) at night, I explained as courteously as possible that it was late and we could sort out the paperwork later. I sent the convoy on its way and when the Sergeant went into the guardroom for advice, I took off. The Sergeant fired at us but fortunately his aim was not accurate. After this foray, we became more secure and more comfortable. 
By about July 1966 shortages were causing significant problems. We had no replacement clothing, boots and personal equipment for our men; the 1944-era tropical-studded boots had provided nourishment for the rubber ants, the clothing had succumbed to wear and tear and could not be replaced, and although we took personal equipment from our administrative elements, we could only put about two thirds of the fighting troops into an operation. During a visit by the Commander, Australian Force Vietnam (COMAFV), Major General Ken Mackay, the CO was wearing a very tattered and torn shirt. When the Commander learned of our plight, he had his headquarters QM Store in Saigon scoured, and we received about 100 sets of clothing and a box of equipment.

Many of the soldiers were not living in tents because the new tents arrived without tent poles, and an RAAF C130 transport aircraft due to bring poles arrived full of toilet paper. The transport ship HMAS Jeparit arrived with many crates empty. We could only construe that there had been sabotage somewhere!

Because of problems with belted ammunition for the M60 GPMG, it was decided to make a sheath for each 100-round belt from inflatable inserts for the field mattresses we usually slept on. This precaution kept rubbish from fouling the belts. However, the ammunition sweated and the steel links, which joined each round to the next, rusted very quickly; so we decided to use regimental funds (non-government moneys owned collectively by the battalion's members) to obtain a gross of WD40 aerosol cans of anti-rust spray. After a few weeks, when the goods had not arrived, we started to investigate and found them, together with crates of GP boots and green floppy hats, on the garbage tip at Vung Tau! Some people at 1 ALSG needed to lift their game.

Food became our next major concern; Australian combat rations were not readily available, and we were forced to use the bulky and unpopular US combat rations. When the battalion was due to return from operations, we would order fresh rations, but most of the time the arrival of fresh rations would seem to signal a need for the battalion to return to operations, where packaged, individual combat rations were consumed. As there was a delay in the installation of cool rooms in our base, the fresh rations quickly became inedible. Indeed, the $\mathrm{CO}$ received, in August, a bill for US\$25,000 for fresh rations; but these were the spoiled fresh rations that had been written off by our RMO and the QM. One soldier asked the $\mathrm{CO}$ not to order fresh rations because with their arrival the 
battalion would be ordered back onto operations. Towards the end of July 1966, the fresh rations system broke down completely and we ate nothing but frankfurts and sweet corn for about five weeks. We had them baked, boiled, fried, grilled and minced. I even sent our warrant officer caterer to fly 300 kilometres to Dalat (in central South Vietnam's highlands) to buy some fresh vegetables; again using money from our regimental funds. The dysfunction of the system was demonstrated by the repeated delivery to our base of fresh rations and ice cream when the battalion was out on operations and while we had no refrigerated storage in base.

By about mid-September 1966, 'home' was becoming more habitable and, while the battalion was on operations, its rear elements built and consolidated the base area. A large movie screen was erected (we were fortunate to find a fisheye cinemascope lens in a US Amenities Unit in Saigon). Also, in the outdoor theatre, named 'The Mayfair', we built a small kitchen to serve steak sandwiches, the inevitable hot dogs plus the CO's favourite, goffers (flavoured milk in a can which could be enjoyed hot or cold - canned soft drinks went by the same nickname). The screen was a beauty, somewhat like the old drive-in theatre screens, I am not sure if any VC, lurking outside the wire, liked our selection of movies! The tents were erected, the cool rooms and refrigeration arrived and were installed. When a couple of Nissen huts arrived, these were allocated to the RMO and padres (chaplains). The rain was dissipating, the weather was cooler at night, the company kitchens and canteens were up and running, and the QM Store started to get some replacement clothing and equipment. During operations and whenever any maintenance resupply to our troops in the field was required, we had the company cooks prepare a meal of hot soup, which we sent out in plastic jerrycans (5-gallon cans similar in appearance to those used by the Germans for the safe carriage of petrol during the Second World War) and steak sandwiches. These fresh meals, delivered during operations, gave our men a welcome break from the monotony of combat rations.

On 18 August 1966, D Company of 6 RAR fought the Battle of Long Tan and used RAAF Iroquois helicopters for combat resupply in late afternoon amid torrential rain. The RAAF performed very well. Prior to this battle, the RAAF seemed to be constrained by hangover peacetime regulations which applied in Australia. After Long Tan we felt that they were full members of the team. However, during Operation Queanbeyan in October 1966, the battalion was required to clear the Nui Thi Vai hills. As the operation progressed, we found occupied caves, live booby 
traps and determined VC opposing us. The $\mathrm{CO}$ decided to clear the caves using flame-throwers. The necessary equipment and incendiary fuel were assembled at Nui Dat and the RAAF Iroquois arrived to fly them across to Nui Thi Vai. The pilot then said he was not permitted to carry fuel in his aircraft. After discussion between myself and the pilot, I consulted higher authority, namely the task force commander, who then brought the RAAF component commander and COMAFV into the discussion. The result was that the RAAF agreed to carry the fuel if the steel jerrycans were packed in wooden crates. In the meantime our troops in close contact with the enemy had to wait while the issue was resolved!

In November 1966, I acted as operations officer while Max Carroll was on rest and recreation leave. During this period, 5 RAR undertook a cordon and search of a small village, Phuoc Hoa, north-west of Ba Ria on Route 15. Immediately following this task, we were required to clear Long Son Island, which was used by the VC as a stepping stone between the Mekong River and the Nui Thi Vai hills. During this operation, the task force commander decided to deploy his headquarters onto the island. These operations gave me a break from administrative duties and provided some operational experience for my next posting as the operations officer at Task Force Headquarters.

I was to leave the battalion in mid-December 1966 after a most eventful year, but one right off the top shelf.

\section{Editors' conclusion}

We have included this chapter, essentially on administrative and logistic matters, to give readers an understanding of how important they are in determining operational capability. As has been demonstrated in the early years of other wars, it takes a long time to prepare a peacetime army for service in war. Moving from a standing start to full operational capability takes a huge effort and demands great determination and ingenuity. We in 5 RAR were very fortunate to have Stan Maizey as our 2IC and principal logistics officer. He had a deep insight into what we needed to have available once we were in operations in Vietnam. He then showed high resolve and negotiating abilities to get what we needed, both in Australia and Vietnam. Once he had seen that we had enough stores and equipment to be able to go to war with confidence, he kept all our stocks of food, fuel, ammunition, tentage and other essential supplies up to the 
level that we required. In personal terms he was one of the battalion's great characters, with a formidable sense of humour, a warm affection for sport, particularly if it offered betting opportunities, and a strong determination to improve the day-to-day lives of our soldiers when they were not on operations by making sure that they were given decent meals and a place in which to relax and enjoy a drink or two. Underpinning his desire to give outstanding service to those who had to rely on him was a very strong personal commitment to 'the Regiment', meaning the Royal Australian Regiment. He saw operational service with a battalion of the Regiment as his highest aspiration and the most satisfying time of his professional life. 
This text is taken from Vietnam Vanguard: The 5th Battalion's Approach to Counter-Insurgency, 1966, edited by Ron Boxall and Robert O'Neill, published 2020 by ANU Press, The Australian National University, Canberra, Australia.

doi.org/10.22459/VV.2019.03 